\title{
Financing Innovation
}

\section{Citation}

Kerr, William R., and Ramana Nanda. "Financing Innovation." Annual Review of Financial Economics 7 (November 2015): 445-462. (Originally Harvard Business School Working Paper, No. 15-034, November 2014.)

\section{Published Version}

https://doi.org/10.1146/annurev-financial-111914-041825

\section{Permanent link}

http://nrs.harvard.edu/urn-3:HUL.InstRepos:13479074

\section{Terms of Use}

This article was downloaded from Harvard University's DASH repository, and is made available under the terms and conditions applicable to Open Access Policy Articles, as set forth at http:// nrs.harvard.edu/urn-3:HUL.InstRepos:dash.current.terms-of-use\#OAP

\section{Share Your Story}

The Harvard community has made this article openly available.

Please share how this access benefits you. Submit a story.

Accessibility 
H A R VAR D

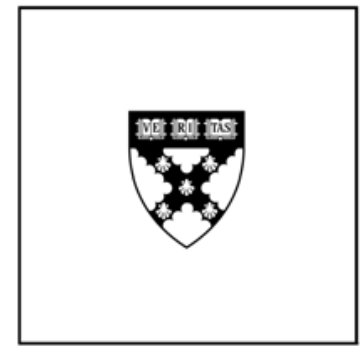

\section{Financing Innovation}

William R. Kerr

Ramana Nanda

\section{Working Paper}

15-034

November 5, 2014 


\title{
Financing Innovation
}

\author{
William R. Kerr and Ramana Nanda \\ Harvard University and NBER
}

\begin{abstract}
We review the recent literature on the financing of innovation, inclusive of large companies and new startups. This research strand has been very active over the past five years, generating important new findings, questioning some long-held beliefs, and creating its own puzzles. Our review outlines the growing body of work that documents a role for debt financing related to innovation. We highlight the new literature on learning and experimentation across multi-stage innovation projects and how this impacts optimal financing design. We further highlight the strong interaction between financing choices for innovation and changing external conditions, especially reduced experimentation costs.
\end{abstract}

Keywords: finance, innovation, entrepreneurship, banks, venture capital, experimentation.

JEL Classification: G21, G24, L26, M13, O31, 032

Comments are appreciated and can be sent to wkerr@hbs.edu and rnanda@hbs.edu. This review is prepared for the Annual Review of Financial Economics. 


\section{Introduction}

There is growing consensus that well-functioning financial markets play a central role in driving economic growth through their ability to spur technological innovation (King and Levine, 1993a,b; Levine, 1997; Brown, Fazzari and Petersen, 2009; Hsu, Tian and Xu, 2014; Comin and Nanda, 2014). One way that financial markets are believed to play this role is by allocating capital to firms with the greatest potential to implement new processes and to commercialize new technologies. This idea, of capital markets funding the most promising projects, harks back to at least Schumpeter's (1934) notion of "creative destruction" and has been actively studied over the last several decades in the context of financing constraints for entrepreneurs (Scherer, 1984; Rajan and Zingales, 1998; Beck et al., 2008) and the impact of institutional reforms that help to make financial markets more efficient (Jayaratne and Strahan, 1996; Bertrand, Schoar and Thesmar, 2007; Black and Strahan, 2002; Cetorelli and Strahan, 2006; Kerr and Nanda, 2009).

Another channel through which financial markets might impact technological development, however, is by financing innovation itself (Hall and Lerner, 2010). That is, while much of the academic literature in finance has focused on the implementation and commercialization of promising ideas, there has been far less focus on whether and how financial markets might actively shape the nature of R\&D that is undertaken, and how this may impact technological innovation and growth through the shaping of the ideas that are developed across firms (Akcigit and Kerr, 2012).

In this chapter, we review a nascent but growing literature that has begun to address this gap in the role that capital markets and financial intermediaries play in impacting firm-level innovation. ${ }^{1}$ In Section 2 , we elaborate on theoretical contributions regarding why financing R\&D projects might be distinct from financing other types of projects and the channels through which financial intermediaries and capital markets can impact innovation. Section 3 discusses the empirical work on financing innovation in mature firms, in particular the literature on how ownership and capital structure impact the amount and nature of innovation undertaken by firms. Section 4 focuses on innovation in startups and the growing literature on the effect that multi-stage financing has on innovation in young firms. Finally, Section 5 discusses the implications of this research and outlines promising areas of future work.

Our review skips over several important aspects of the phenomenon that Hall and Lerner (2010) cover in substantial depth. These topics include an extensive depiction of how R\&D differs from normal investment, the tax considerations associated with R\&D and the role of R\&D tax credits in stimulating innovation, the large literature on cash flow sensitivities for R\&D and associated interpretations, detailed depictions of the venture capital (VC) cycle, and others. We refer readers to this earlier review for these complementary pieces. We instead concentrate on very salient discussion points in the current

\footnotetext{
${ }^{1}$ We focus this review on the financing of innovation and thus skip many other important factors for innovation: for example, the role of intellectual property (Williams, 2013), demand-side factors such as the size of the market (Acemoglu and Linn, 2004), the supply of talented scientists and engineers (Kerr and Lincoln, 2010), and spillovers across firms (Bloom, Schankerman and Van Reenen, 2013). Nicholas (2011) provides a recent review. In addition, we leave out the literature on the impact of technological revolutions on financial markets (Pastor and Veronesi, 2009), which is related to asset pricing rather than the real effects of corporate financing choices.
} 
literature, and we favor outlining recent papers (while still mentioning many classics). ${ }^{2}$ Our understanding of the financing of innovation has grown a lot in five years, but our review highlights that the recent literature challenges some long-standing wisdom and creates new puzzles, suggesting this area of work will continue strongly for some time into the future.

Looking forward through this review, we highlight several recent themes for the financing of innovation that cut across section boundaries. First, there is a growing body of work that documents a role for debt financing related to innovation. While somewhat unexpected given the older literature and the properties of debt/collateral, we describe how the settings in which debt is used for innovation are reasonable and perhaps more prevalent than anticipated. In parallel, the recent literature emphasizes some limits of equity markets for financing innovation, especially radical forms, due to short-term pressures, imperfect monitoring, and similar. This recent work suggests that an important area for continued research is to go back to the basics of banks and their connection to innovation.

Second, we highlight the new literature on "learning" across multi-stage financings, which has been a very active area of research. Most of the early literature focuses on agency issues in financial contracts, and a surge of research now considers the trade-offs associated with stimulating innovation when agents are experimenting and adapting their work across periods. This line of research is very important for developing greater insights into how financing can impact the forms of innovation (e.g., exploration vs. exploitation) rather than just a generic R\&D. We describe the variety of theoretical and empirical results that are assembled, attempt to place some structure around the work, and also note the need for future research to continue clarifying the critical dimensions and conflicts (e.g., the distinctions between optimal financing for single innovations vs. blanket policies that must apply to many firms).

Finally, we highlight the strong interaction between financing choices for innovation and changing external conditions. This, of course, has a long academic history dating back to depictions of the differing external financing needs of industries, the impact that vibrant public equity markets can have for innovation, etc. We draw out in this review the important impact that the falling cost of experimentation can have on financing innovation (e.g., the rise of angel investments and accelerators, greater use of multi-stage contracts). Recent research also describes the limits to this model for financing innovation-for example, the financing or rollover risks that can occur with extensive capital needs if one must return repeatedly to financing markets. We also describe the connection between these financing conditions/models and the adjustment costs of innovation. Some models of innovation and its financing smooth bumps as much as possible (e.g., to protect tacit knowledge within the firm), while others engage in much more rapid adjustment. Looking forward, we anticipate future work being able to articulate better where each framework applies and how they fit together.

\footnotetext{
${ }^{2}$ Similarly, Lerner and Seru (2014) provide insights for finance scholars on the appropriate empirical use of patent data, which we do not consider in this review.
} 


\section{Financing Innovation: Theory}

In a frictionless world, where all positive NPV projects are financed, one should not expect the sources of finance to impact the nature of innovation being conducted by a firm. At least four features of the $R \& D$ process, however, introduce important frictions, and these frictions can lead to financing constraints for firms aiming to undertake $R \& D$, as well as impact how the sources of capital have a bearing on the outcome of the innovation process.

First, the innovation process is inherently uncertain. Knight (1921) stresses that uncertainty is fundamentally different from risk. Not only does one not know the probabilities associated with outcomes, but even the forms of the potential outcomes are not clear. For example, looking forward from today, at what rate, if at all, will electric cars replace traditional automobiles and how will the supporting architecture for battery recharging be designed? What will be the impact of nascent augmented reality techniques for how humans interact? Which, if any, of the several ideas to cure cancer are most promising? From a financier's perspective, this makes it significantly harder to evaluate potential innovative projects that may require funding, particularly since often the only way to learn about the potential of a particular approach is to invest in it. This raises significant possibilities of financing constraints arising in the funding of innovation. In addition, the payoffs associated with making an investment and the way it is structured (e.g., debt vs. equity) can have important effects on what is financed and how financiers might shape the direction of R\&D and innovation.

Second, the challenge of making investments in the face of extreme uncertainty is compounded by the fact that the return from the innovation process is extremely skewed (e.g., Scherer and Harhoff, 2000). In fact, there is some evidence that the distribution of profits from innovation may hold characteristics of a Pareto distribution, where the variance does not exist or converge in large samples. Standard ways of evaluating projects are therefore extremely difficult, and it often requires specialized intermediaries to take on such investments, particularly those backing young, startup firms. These intermediaries make judgments about whether to fund projects based on their own heuristics. Furthermore, their backgrounds and incentives may lead them to interpret and act on information differently, leading financiers to have a first-order effect on innovation (e.g., Kerr, Nanda and Rhodes-Kropf, 2014).

Third, although often times neither the innovator nor the financier knows the true potential of the project, the innovator may still know more about the project than the financier. It is often impossible to accurately measure inputs into the innovation process (e.g., Holmstrom, 1989), and one cannot write complete, state-contingent contracts when one does not even know what the output might be (e.g., Grossman and Hart, 1986; Hart and Moore, 1990; Aghion and Tirole, 1994). These conditions allow for agency costs to arise in the financing of innovation that can be significantly greater than those present in standard settings between financiers and entrepreneurs.

Finally, firms engaged in innovation have a high percentage of intangible assets, where knowledge is embedded in the human capital of the firm's employees. This key resource is lost if employees leave or are laid off (e.g., Hall and Lerner, 2010). Firms therefore tend to smooth R\&D spending over time, in 
order to avoid having to lay off their research scientists and knowledge workers, leading R\&D spending at the firm-level to behave as if it has high adjustment costs (e.g., Hall, Griliches and Hausman, 1986).

These particular attributes of R\&D have an important bearing on how the financial sector impacts innovation that is undertaken by firms.

\section{Finance and Innovation in Mature Firms: Capital Structure, Governance and Agency costs}

\subsection{Financing constraints and innovation}

Much of the early literature on finance and innovation sought to document the particular challenges associated with financing R\&D and to quantify the degree to which innovative firms faced financing constraints (e.g., Brown, Martinsson and Petersen, 2012). An important paper in this field is Brown, Fazzari and Petersen (2009), who provide evidence that young, high-tech, publicly-traded firms finance their R\&D investment almost entirely through internal cash flow and external equity markets. They argue that "information problems, skewed and highly uncertain returns, and lack of collateral value likely make debt a poor substitute for equity finance" (p. 152). Therefore, to the extent that these firms face financing constraints, exogenous changes in the supply of external equity should have significant effects on R\&D. Brown, Fazzari and Petersen (2009) argue that the US experienced a finance-driven cycle in R\&D from 1994 to 2004, when privately financed R\&D to GDP rose from $1.4 \%$ in 1994 to $1.9 \%$ in 2004 and was driven by the young, publicly-traded firms in seven high-tech industries that benefited from the stock market boom in that period. They argue that their estimates can explain $75 \%$ of the aggregate R\&D boom and subsequent decline.

Acharya and $\mathrm{Xu}$ (2013) find evidence that is consistent with the importance of public equity markets to finance innovation. They find that publicly-traded firms in industries that are more dependent on external finance generate more patents that are of higher quality and novelty than privately-held firms, but that this difference does not exist for firms in industries that are less dependent on external finance.

Nanda and Nicholas (2014) examine firms during the Great Depression as a way to understand the effects of financing constraints on innovative activity. They are motivated by the fact that the large productivity drop from 1929 to 1933 was contemporaneous with and followed by enormous technological surges in industries like chemicals, television and radio, and the automobile (e.g., Raff and Trajtenberg, 1997). In fact, Field (2003) shows that the 1930s was the most innovative decade of the twentieth century. If finance is so central to innovation, how can it be reconciled that innovation progressed so well in a period that experienced one of the largest shocks to the banking system, in addition to disrupting the public debt and equity markets?

Nanda and Nicholas (2014) match historical patents to firms in this time period and thereby trace innovation being undertaken in different counties. Since state-level regulations implied that bank financing tended to be local at this time, their empirical work can exploit variation in the intensity of the 
bank suspensions across counties to examine the effect it had on firm-level innovation. They find that the sharp drop in the availability of external bank finance not only impacted the rate of innovation, but changed the trajectory of innovation away from more experimental, radical innovations to incremental and sustaining innovations. That is, they are able to trace the effect of the disruption in the availability of capital to real effects in terms of innovation. These effects were sharp, but firms recovered quickly. Importantly, it was only the firms in capital-intensive industries located in the worst-hit counties that were adversely affected, which might explain why the overall effects were not as large.

An attractive feature of their setting is that they are able to look at the cumulative citations to innovations undertaken in the 1930s over the period 1947-2008 and therefore examine the long-run effects of this sharp disruption in the availability of external finance. A startling fact is that the cumulative citations to firms innovating in the 1930s and located in counties with greater levels of bank distress continue to be lower than those undertaken by firms located in counties facing less bank distress. Although the effect on patenting rates and trajectory was short-lived, the consequences are long standing, suggesting that financing constraints can have first-order and persistent effects on cumulative innovation undertaken in the economy.

\subsection{The (surprising) importance of bank finance in innovation}

Although early research on capital structure and innovation pointed strongly against the role of banks (and debt) in financing innovation, as discussed extensively in Hall and Lerner (2010), subsequent work has been more nuanced. Similar to Nanda and Nicholas (2014), there seems to be growing evidence that bank finance is an important source of capital, even for firms engaged in innovation. Moreover, changes in the availability or cost of bank finance have been shown to impact both the rate and nature of innovation by firms. There is also growing evidence that the public equity markets have their own forms of agency costs and that resulting managerial myopia (e.g., Stein, 1988) can stifle innovation.

Looking first at bank financing, Mann (2014) shows that debt financing is not only common for innovating firms, but that furthermore, patents are often used as collateral in such instances. He notes that $16 \%$ of the aggregate stock of patents at the US Patent and Trademark Office (USPTO) has been pledged as collateral at some point, and that companies with patent-backed debt have performed over $40 \%$ of USPTO patenting since 2003 . He documents that the amount of credit is economically large and seems to directly finance research. He also documents that lenders are frequently banks, but may also be venture debt or other non-bank lenders. Similarly Hochberg, Serrano and Ziedonis (2014) find patents are used as collateral for venture debt, and Chava, Chong and Nanda (2012) find firms with significant patent activity and higher-quality patents receive cheaper bank loans than peers.

Robb and Robinson (2014) show that external bank finance is an important source of startup capital, even for high-potential startups that might be engaged in innovation and who don't have any collateraltangible or intangible-to pledge. Consistent with this, Chava et al. (2013) find that the US banking deregulations over the 1980s had a measurable effect on innovation, particularly by small firms who would have been more likely to be financially constrained. They find that innovation fell following the 
intra-state banking deregulation, but went up following the inter-state deregulations. Interestingly, they also find that the deregulations impacted the nature of innovation undertaken, in that the increases in innovation following the inter-state deregulations were also associated with a greater variance in the quality of the patents, as proxied by their subsequent citations. Thus the increased competition seems to have facilitated a greater level of higher-risk innovations among smaller firms. Similarly, Cornaggia et al. (2013) find that innovation by small private firms, who depend more on bank finance for capital than publicly-traded firms, increased following the inter-state deregulations, while innovation fell among publicly-traded firms. Cornaggia et al. (2013) argue that this latter effect is driven by an increased negotiating ability of innovative targets, which are less likely to be acquired and instead continue on as standalone firms due to the greater ability to access external finance.

This growing body of work suggests than an important and underexplored area is the ways in which banks lend and monitor the financing of innovation. This is not only an important area to study, but it has potentially deep implications for theory and extensive literature that suggests that the linkage should be quite different.

\subsection{Costs associated with being public: Managerial career concerns and other agency costs}

There is growing evidence that agency costs associated with being a publicly-traded firm can adversely impact the rate and trajectory of innovation. This deterioration is despite equity having several properties that are attractive from a governance perspective (e.g., aligning the interests of investors and innovators to take on risky projects) and sufficient market depth to alleviate financing constraints.

Bernstein (2014) provides an important contribution by documenting the causal effect of going public on firm-level innovation. He exploits the fact that firms that file to go public are more likely to pull back from their planned public offering if there are sharp declines in the public markets during their bookbuilding phase. He therefore uses NASDAQ fluctuations in the two months following an IPO filing as an instrument for the final going-public decision. Using this identification strategy within his sample of private firms filing to go public, Bernstein (2014) finds that the private-to-public transition does not impact a firm's rate of innovation, but it does reduce the novelty of innovations produced as proxied by patent citations by $40 \%$. Extensions suggest that this latter drop is due to a departure of productive scientists engaged in innovation and by the shift in the type of R\&D being undertaken by scientists who remain in the publicly-traded firms. This fascinating result suggests that the governance associated with the public markets has a causal effect on the nature of innovation undertaken within transitioning firms.

Bernstein argues that his findings are driven by the agency costs between shareholders and managers that are introduced when firms go public. For example, Holmstrom (1982) develops a model where managers have private benefit of control and need to decide whether or not to innovate. In his model, innovation is highly uncertain and may go wrong for purely stochastic reasons, leading shareholders to mistakenly attribute a failure to managerial skill, potentially costing the manager's job. Managers are therefore concerned about the impact of innovation on investors' perception of their ability, leading them to under-invest in innovation relative to the optimum. This is particularly true when a firm goes 
public and faces a diverse shareholder base that has lower monitoring incentives. Similarly, Stein (1988) develops a model of managerial myopia in which shareholders cannot properly evaluate investments in long-term innovative projects due to asymmetric information, and therefore markets tend to undervalue the stocks of companies engaged in such projects. In Stein's model, this undervaluing of innovative companies makes it easier for hostile acquirers to obtain control of the company. To protect current shareholders against such expropriation, therefore, managers rationally invest less in innovative projects that are difficult for the market to understand, and more in routine projects with quicker and more-certain returns. This leads to a decline in innovation by publicly traded firms.

Bernstein's work is related to other recent research that documents the extent to which these agency costs are important among publicly-traded firms and how they impact innovation. For example, Aghion, Van Reenen and Zingales (2013) look at the effect of institutional ownership on innovation. They find that greater institutional ownership leads to greater innovation, and that the channel is consistent with models of managerial career concerns (e.g., Edmans, 2009; Holmstrom, 1982), where increased institutional ownership raises the incentives to monitor CEOs and thereby insulates them from being fired for bad outcomes unrelated to their management decisions. They find, for example, that CEOs are less likely to be fired in the face of profit downturns when institutional ownership is higher. Similarly, Francis and Smith (1995) find a positive correlation between ownership concentration and R\&D expenditure, and Bushee (1998) finds that companies with greater institutional ownership are less likely to cut R\&D following poor earnings performance. He and Tian (2013) document that increased analyst coverage leads to less innovation by publicly-traded firms, and argue that this is driven by the pressure that CEOs face to meet short-term goals. Lerner, Sorensen and Stromberg (2011) show that patents by portfolio firms of private equity investors are of higher quality and are more concentrated in the most important areas of companies' innovative portfolios. They argue that the private equity investors boost innovation and discipline among their portfolio companies by relieving managers of the short-term pressure of displaced shareholders.

Empirical work looking at managerial myopia in the context of anti-takeover provisions along the Stein (1988) model has also found that it has an effect on innovation, although the findings are more contradictory. For example, Atanassov (2013) finds that innovation falls in states that pass anti-takeover laws and argues that this is because the negative effects of managerial entrenchment when it is harder to take over a worse-performing firm seem to outweigh any benefits associated with a fall in managerial myopia. On the other hand, Chemmanur and Tian (2012) find that innovation is higher in firms with more anti-takeover defenses. In addition, Fang, Tian and Tice (2013) argue that increased stock liquidity hurts innovation, in part because firms face a greater threat of hostile takeovers. We discuss these results further in Section 3.5 below.

To summarize, while the literature on capital structure and its effect on governance and agency costs is somewhat contested, there are some broad themes that consistently emerge from this body of work. First, bank finance appears important for innovation, but it is likely to be better suited to financing larger and mature companies, where investment is less risky for banks due to the firm's sufficient cash flow from operations and collateral options from fixed assets and patents. This would be in line with Hall and Lerner's (2010) depiction of the lower cost of bank financing compared to financing out of retained 
earnings. Second, while equity investors might be more willing to finance risky innovation, public equity markets impose an important set of agency costs on managers that can impact the rate and nature of innovation. Finally, the costs and benefits associated with being private vs. public are heterogeneous across firms, and research to understand these tradeoffs is a promising area of future work. For example, Ferreira, Manso and Silva (2014) argue that public firms may be best positioned to commercialize innovations that benefit from greater depth and liquidity of the public capital markets, but that private firms are better suited for novel and exploratory innovation.

\subsection{Internal capital markets and employment contracts}

While the majority of the finance literature on innovation in mature firms focuses on the tradeoffs associated with different sources of external finance, there is also evidence that the capital budgeting process and compensation structures within firms can have a meaningful effect on corporate innovation.

Seru (2014) compares the innovation of firms that were targets in failed mergers to those where the merger or acquisition was successful. Firms acquired in diversifying mergers tend to have fewer patents and less-novel innovations going forward than firms that were failed targets of bids. Seru finds that this effect is magnified when the acquiring conglomerate operates a more-active internal capital market and argues that this is due to inventors becoming less productive after the merger. ${ }^{3}$

The change in productivity of inventors documented by Seru (2014) and Bernstein (2014) is important evidence that the governance associated with external and internal capital markets follows through to employment contracts within firms. Understanding the optimal contract to encourage innovation by inventors is therefore an important element for promoting innovation.

Understanding optimal contracts in the face of principal-agent problems has a long tradition in corporate finance and organizational economics, harking back to seminal principal-agent models, such as Holmstrom (1989) and Aghion and Tirole (1994). For example, Holmstrom (1989) argues that optimal contracts to stimulate innovation should rely on compensation schemes that are less sensitive to performance due to the noisy metrics for assessing innovative outcomes. Aghion and Tirole (1994) argue that the outcomes of innovation activities are unpredictable and, therefore, hard to contract ex ante. In an incomplete contract framework, they derive the optimal allocation of control rights that motivates innovation. These papers focus on measurability and contractibility aspects of the innovation activity.

The focus of these early models is on asymmetric information between the principal and the agent. The agent does not learn about the distribution of payoffs through the innovation process. Moreover, the agent takes an action in the first period and cannot change it later on. Therefore, these models do not incorporate learning and hence experimentation, which are important features of innovation. An

\footnotetext{
${ }^{3}$ The effect of organizational structure on the commercializing of innovations has been studied in the context of spinoffs (e.g., Gompers, Lerner and Scharfstein, 2005) and in theoretical work looking at the compensation contracts between the firm and the potential entrepreneur (e.g., Anton and Yao, 1995; Hellman, 2007).
} 
important contribution on the optimal design of compensation contracts comes from Manso (2011), who combines the ability to learn with asymmetric information in a principal-agent model to study incentives and optimal contracts to stimulate innovation. Manso shows that the optimal incentive scheme that motivates innovation can exhibit substantial tolerance for early failure and reward for longterm success. That is, since the principal wants the agent to explore, it may be optimal at times to encourage the agent to take unconventional paths (even if they lead to failure), by committing not to punish the agent for negative results in intermediate periods, but instead to focus on rewarding longterm success. Thus, committing ex ante to inefficient continuation ex post may be optimal to induce exploration since the threat of termination may prevent the agent from exploring new untested approaches. In the context of managerial compensation, the institution of tenure, stock options with long vesting periods, and managerial entrenchment are all features of contracts that might stimulate more exploratory innovations.

Indeed, Lerner and Wulf (2007) show that US corporations have been shifting compensation of the heads of corporate R\&D to align them better with the objectives of the firm and to provide long-term incentives, such as stock options that are associated with more patents or greater novelty. Similarly, Gonzales-Uribe and Xu (2014) show that firms whose CEOs have more years remaining on their contract invest significantly more and are associated with higher-quality innovation than peer firms whose CEOs have fewer years remaining on their contracts.

\subsection{Legal and institutional environment and innovation}

The Manso (2011) framework for tolerating early failure and rewarding long-term success has also been studied in the context of institutions that might promote entrenchment or protect employees from being fired. For example, it has been argued that anti-takeover laws might stimulate radical innovation because they promote entrenchment, that lenient bankruptcy laws may promote more exploration, and that laws that make it harder to fire employees may lead to more novel innovations.

However, both the theory and the empirical results here are more ambiguous, due to the confounding effects of selection and treatment. Manso (2011) describes the optimal contract under different types of project characteristics and hence, for example, would prescribe a different bankruptcy law depending on whether the objective was exploration or exploitation (e.g., Ederer and Manso, 2011). Similarly, the degree to which employment protection or anti-takeover provisions are helpful or harmful for innovation depend on the nature of innovation that is being sought after.

In practice, however, innovation has many shades of grey between the binary exploration and exploitation archetypes, and furthermore, it is impossible for policy makers to provide an ex ante optimal law for each type of innovation being undertaken. The fact that policy makers can create a blanket policy regardless of the nature of innovation being undertaken therefore leads to a trade-off between the ex post treatment effect of the policy and the ex ante selection into the regime (Nanda and Rhodes-Kropf, 2012). For example, Acharya and Subramanian (2009) find that employment protection laws stimulate innovation by large firms, appealing to the Manso (2011) model. On the other hand, 
Bozkaya and Kerr (2014) find that countries with more stringent employment protection laws are less likely to attract VC investment, especially in volatile sectors that are associated with extremely radical innovations. These results conform better to the theoretical predictions of Saint-Paul $(1997,2002)$ and Samaniego (2006) who model how labor adjustment costs discourage specialization in industries that require frequent labor adjustment, which the VC model particularly depends upon.

Similarly, Acharya et al. (2013) find that lenient bankruptcy laws promote innovation, suggestive of a greater willingness to take on risky projects with stronger downside protection. However, Berkowitz and White (2004) find that firms located in states with more-lenient bankruptcy laws are less likely to receive credit in the first place because banks are not as willing to lend under the unfavorable regime. Cerqueiro et al. (2014) find that this lower likelihood of receiving credit also translates into less innovation by firms that are more dependent on bank finance. This is also similar to Mann (2014), who finds that stronger creditor rights are associated with greater innovation by firms in his sample. Finally, as introduced above, Chemmanur and Tian (2012) find evidence that anti-takeover provisions promote innovation, while Atanassov (2013) finds that the negative effects of managerial entrenchment dominate the potentially positive effects of promoting exploration. Chemmanur, Loutskina and Tian (2014) find that corporate VC investors tend to back more novel startups, but that these startups also perform worse, suggesting that novelty may come at an economic cost to the investor.

The evidence of these tradeoffs suggests that more work is warranted to understand the effect on policy. For example, Nanda and Rhodes-Kropf (2012) show how strategies to promote innovation by building in ex post failure tolerance have the potential to reduce radical innovation because the inability to terminate poorly performing projects leads principals to only start projects with relatively low option value. As we describe further in the last section, our conclusion from the recent work is that more thought needs to be placed into the frameworks that sit behind models and into understanding better how empirical tests shed light on particular models.

\section{Finance and Innovation in Startups}

Although the majority of the literature on financing innovation focuses on mature firms, we outline next theoretical and empirical work on the fundamental role of young, small firms in driving the most radical innovations in the economy. We then outline several lines of empirical work that document the important role that financial intermediaries and financial markets may play in the rate and trajectory of innovation by startups.

The important role of innovation by small firms was documented as early as Acs and Audretsch (1987), who looked at the introduction of new products, processes and services and found that a disproportionate share of these came from small firms. Ewens and Fons-Rosen (2013) find that individuals who transition from large companies to founding a startup change their patenting behavior

to focus on riskier, more innovative patents. Akcigit and Kerr (2012) similarly provide theoretical and empirical evidence for the importance of small firms in exploration R\&D, with larger firms focusing a 
greater share of their effort on internal innovations that build the profit margins on existing products. An important part of this model is that these differences between large and small firms can arise even when firms have access to the same innovative capabilities, instead being due to differences in profitmaximizing investment choices governed by firm size. ${ }^{4}$ Nanda, Younge and Fleming (2015) show substantial differences in the degree to which large incumbents in clean energy and startups engage in exploration and exploitation, even in a relatively "new" industry.

\subsection{Venture capital and startup innovation}

The majority of empirical work on financing innovative startups considers VC investments. Hall and Lerner (2010), Da Rin, Hellmann and Puri (2013), and Cumming and Johan (2009) provide comprehensive reviews. An important early contribution in this field was by Kortum and Lerner (2000), who documented the causal effect of VC on innovation using a policy shift that led to greater allocation of pension fund capital to VC firms. Kortum and Lerner document that increases in venture capital activity led to greater patenting rates and may have accounted for $8 \%$ of the industrial innovations during their period of study. Subsequent work by Samila and Sorenson (2011) also quantifies how VC investment encourages economic growth in local areas, and Kerr, Lerner and Schoar (2014) find that startup patenting is boosted by investment from two angel investment groups when comparing justfunded deals to those missing the cutoff.

Bernstein, Giroud and Townsend (2014) show that one mechanism through which VC investors impact startup innovation is through their role in monitoring, suggesting the important role of governance in this context. This is consistent with the work of Lerner (1995), Gompers (1995), Hellman and Puri (2000; 2002) and Chemmanur, Krishnan and Nandy (2011) who document the important role that VC investment approaches and contracts play in overcoming agency issues through staged financing, monitoring, board representation, and replacing founders with professional CEOs in the case of underperforming ventures (e.g., Wasserman, 2003).

\subsection{Experimentation and learning in multi-stage financings ${ }^{5}$}

Similar to the literature on mature firms, there is growing work within the VC literature on the role of learning and the ways in which it interacts with potential agency issues. For example, Kerr, Nanda and Rhodes-Kropf (2014) document the extreme difficulty, even for professional investors like VCs, to judge the potential success of innovative startups at an early stage of their investment. Indeed, given the extreme uncertainty associated with these investments ex ante, and the skewness in ex post returns

\footnotetext{
${ }^{4}$ An extensive literature in management focuses on these issues, emphasizing the negative impact of established routines and practices in large, bureaucratic organizations for exploratory work. Lerner (2012) provides a recent review.

${ }^{5}$ Parts of this section draw on Kerr, Nanda and Rhodes-Kropf (2014), who also document the trade-offs associated with multi-stage financings.
} 
where a few investments account for the vast majority of the VC portfolio returns, the experimentation paradigm plays a central role in VC investors' approach to the financing of innovative startups.

Bergemann and Hege $(1998,2005)$ consider staged VC financing as a series of real options with an optimal stopping point, documenting how a number of features associated with VC contracts represent responses to dynamic learning in the face of agency concerns. Their model is different from Manso's (2011) model in that there is no safe path to pursue in the event that the entrepreneur and investor learn that the project is not viable. This seems more appropriate to the VC context, where firms are commercializing technologies that are often "new to the world" rather than "new to the firm", and hence there is little they can do if there is no traction in terms of the project. ${ }^{6}$

The real options framework provides several other useful insights in the context of VC. For example, Nanda, Younge and Fleming (2015) document the mismatch between VC and certain industries such as clean energy, where the capital and investment timeframe that is required to learn about the viability of a project is so high that innovative projects with great potential are not funded without the support of government. Howell (2014) shows the important role that government subsidies can play in reducing initial financing constraints in such cases. ${ }^{7}$

Moreover, Kerr, Nanda and Rhodes-Kropf (2014) document how the falling cost of learning about viability in the early stages of a technology can have a profound effect on experimentation by earlystage investors. While these changes are most obvious in the context of entrepreneurship in software and consumer-facing internet startups, where cloud computing and object-oriented programming have lowered the cost of starting businesses substantially, there have been dramatic falls in the cost associated with simulation technologies, rapid prototyping and bio-informatics (gene-sequencing), also leading to a surge in investor interest in funding innovation in these sectors.

Ewens, Nanda and Rhodes-Kropf (2014) highlight that the fall in the cost of experimentation reduces financing constraints for projects with the greatest option value, and thus the effects should be particularly salient for young, inexperienced founders or for those projects where early indications of prospects for the project can impact the trajectory of future investment significantly (e.g., investment in nuclear startups following simulations of reactor cores). Indeed, the timing of the dramatic rise in accelerators (starting in 2005) to help inexperienced entrepreneurs scale companies (e.g., Cohen and Hochberg, 2014; Yu, 2014), first in software and more recently in hardware and genomics-based startups, seems very consistent with the fact that the biggest beneficiaries of the falling cost in experimentation have been young, inexperienced entrepreneurs.

\footnotetext{
${ }^{6}$ In such cases, the agency issues facing investors are also different. For example, the entrepreneur may have a bias for inefficient exploration with a project that has a negative intermediate signal, given that they have no alternative path to pursue. For example, Guedj and Scharfstein (2004) find that drugs being commercialized by biotech firms are more likely to pass Phase I clinical trials compared to pharmaceutical firms, but conditional on reaching Phase II, are less likely to progress to Phase III.

${ }^{7}$ Fabrizio (2007) documents at the role of federal government in financing major innovations. Lerner (1999) studies the Small Business Innovation Research (SBIR) programs that dedicate millions of dollars each year to funding the commercialization of innovations. We do not delve in this review into the extensive literature on financing innovation in government and university labs.
} 
Successful experimentation requires being able to abandon poorly performing investments, but also to capitalize on experiments that reveal positive outcomes, and these upside scenarios can be as tricky as termination decisions. ${ }^{8}$ One reason is that financing projects in stages requires that startups return to the capital markets at regular intervals for more capital, making entrepreneurs and early-stage investors vulnerable to swings in financial markets. At times, financial capital is freely available, while in other instances it is hard to come by even for good projects. These financing constraints can be market-wide or they can be specific to sectors due to the degree to which investors herd around certain hot industries.

VC investors routinely refer to "financing risk" (similar to rollover risk) to describe how otherwise-sound projects may not obtain capital for the next stage of experiment. Financing risk arises when a single investor lacks the capital to fund a startup to being cash flow positive, and hence investors need to coordinate across financing rounds with future investors. One way to protect against financing risk is to go less frequently to the capital markets, taking larger chunks of money at each stage (thereby leading to coordination between contemporaneous investors). This approach, however, reduces the value of the abandonment options for VC firms. Nanda and Rhodes-Kropf $(2010,2013)$ argue that hot marketstimes when financing risk is low-allow projects with the highest real option values to be funded because the continuation risk is lower. Empirically, these are times when VC-backed firms have the highest failure rates, but conditional on being successful, these startups have higher-valued exits compared to startups funded in less-active periods that are exiting at the same time.

Financing risk is most salient for projects that need to go back to the capital markets many times, and thus the projects that are worst hit are often experimental new technologies. In fact, a possible implication of this work is that the most innovative projects in the economy may need times of low financing risk ("hot financial markets") to drive their initial commercialization, a conclusion connected to the role of stock markets in financing innovation (Brown, Fazzari and Petersen, 2009). ${ }^{9}$

Financing risk is representative of a broader class of continuation features that govern the degree to which experimentation can be pursued. One example compares clean energy and biotech, as biotech also requires substantial investment and very long horizons but is the beneficiary of substantially more VC investment than clean energy. Biotech startups and the pharmaceutical industry are part of a vibrant "market for ideas" (Gans, Hsu and Stern, 2002) that allows biotech companies to sell the results of their experiments at milestones. That is, a biotech company can undertake a first experiment to show that a project that originally seemed to have had a 0.1 percent chance of becoming a block-buster drug has in fact a 5 percent chance. This experiment has generated substantial information value, and pharmaceutical companies are willing to buy the remaining 1-in-20 opportunity for their drugdevelopment portfolios. This market works because the science used in the first experiment is observable and verifiable, a patent system protects the startup from intellectual theft, and the longterm opportunity is more protected compared to clean energy innovations (which can face competition

\footnotetext{
${ }^{8}$ Similarly, systems that facilitate high-value exits such as equity-market vs. bank-oriented financial systems (e.g. Black and Gilson, 1998) might be particularly valuable for attracting startups engaged in innovation.

${ }^{9}$ Similarly, Hochberg, Serrano and Ziedonis (2014) find that the credibility of VC commitments to provide another round of financing to a startup plays an important role in their ability to attract venture debt.
} 
from all alternative sources of energy, including opening up strategic oil reserves). Such a "market for ideas" is much less developed for clean energy, and as a consequence entrepreneurs and investors who are considering an experiment in this area face additional continuation risks (Nanda et al., 2015).

\section{Conclusion}

The nascent, but fast-growing literature on the financing of innovation has made large advances in recent years. The literature has focused on several key themes. First, there is clear evidence that financing constraints have the possibility to be considerable in the context of firms engaged in R\&D and innovation - with the ability to shape both the rate and the trajectory of innovation. Second, capital structure plays a central role in the outcome of innovations. Bank finance is an important source of finance, particularly for larger firms with tangible and intangible assets to pledge as collateral. Alternatively, public markets provide deep pockets but pose a set of agency costs that might be particularly harmful for firms engaged in exploration and novel innovations. Third, there is a growing interest in the multi-stage financing of innovation, both in established firms and startups, and understanding the optimal contracts and policies that might stimulate innovation.

As we move towards a consolidation of knowledge in this field of study, there are a number of promising areas of further investigation, as well as best practices that might facilitate cross-study comparison of magnitudes and a deeper understanding of trade-offs involved. The first relates to measurement of innovation. The standard approach to measuring innovation has been to look at the volume of patenting and at patent citations. While these metrics have been linked with economic value (e.g., Trajtenberg, 1990; Kogan et al., 2012), deeper analyses of patent- and non-patent based measures of innovation are likely to yield significant insights into the effect of finance on innovation. For example, many recent studies have picked up on exploration and exploitation themes. Most papers tend to use patent-based measures of innovation to quantify these properties, but there is no clear standard of how to approach this exercise. The number of forward citations to patents is the most common metric used, given the believed role of experimentation and exploration for yielding outcomes in the tails of the distribution, but other measures like the backwards self-citations of firms can provide insights as well (e.g., Akcigit and Kerr, 2012). Similarly, studies need to report a battery of typical metrics like the originality and generality of the patents, even where null results are found, so that papers can begin to speak a common language. In addition, there may be significant value to looking beyond citation-based measures of innovation and also examining innovation that is not based on patents themselves.

Second, as has been pointed out above, there are contradictory findings about the impact of capital structure, laws and contract design on innovation. Indeed, the literature has uncovered as many disagreements as agreements since Hall and Lerner (2010). Understanding optimal contracts and laws is complicated by the fact that while it may be possible to derive the optimal contract in an individual case, thinking about policies involves trade-offs in equilibrium. Studying these trade-offs and their net effects seems to be a particularly promising area of research in this space. Likewise, empirical research too often sets out on a shotgun search to find evidence for a recent finance-innovation theory, neglecting 
that each theory is set within a framework of assumptions and abstractions, and thus care should be exercised about choosing empirical settings to test theories.

Third, much of the research focuses on micro-level studies of innovation, and the development of a better understanding of how the macroeconomic environment interacts with and is influenced by financing choices facing firms is a particularly important area going forward. The scope of this review does not allow us to document the literature in this regard (e.g., Cagetti and De Nardi, 2006; Aghion et al., 2012), which is growing up in parallel to the micro-based studies described here. We hope that future research bridges more systematically this span. For example, how much of aggregate TFP growth or other macro-measures of innovation can we account for through the differences in financial systems or financing choices? That is, while we might agree that finance has an impact on real outcomes such as innovation, how large an impact is this?

Finally, and perhaps most speculatively, we think that the role of adjustment costs in innovation deserves extra attention going forward. Much of the early work on corporate R\&D describes important adjustment costs that lead to smoothing of innovative efforts. This protects special firm assets and also leads to particular financing needs. On the other hand, much of the recent work focuses on settings where adjustments are very rapid (e.g., staged financing by VC firms). The agglomeration/clustering of entrepreneurial finance and innovative firms reduces some adjustment costs (e.g., Carlino and Kerr, 2014), recent technological advances lower others, and this connects to industrial organization and modularity of innovation (e.g., Fallick, Fleischman and Rebitzer, 2006). Both perspectives appear to hold substantial merit, and Lerner (2012) describes the advantages and liabilities of the various models for approaching innovation. Completing this review, we are left wondering whether a more comprehensive framework can be developed here. 


\section{References}

Acemoglu, D., \& Linn, J. (2004). Market size in innovation: Theory and evidence from the pharmaceutical industry. Quarterly Journal of Economics, 3, 1049-1090.

Acharya, V., Baghai, R.P., \& Subramanian, K.V. (2013). Wrongful discharge laws and innovation. Forthcoming, Review of Financial Studies.

Acharya, V., \& Subramanian, K.V. (2009). Bankruptcy codes and innovation. Review of Financial Studies, $22,4949-4988$.

Acharya, V. \& Xu, Z. (2013). Financial dependence and innovation: The case of public versus private firms. NBER Working Paper No. 19708

Acs, Z.J., \& Audretsch, D.B. (1987). An empirical examination of small firm growth. Economics Letters, 25, 363-366.

Aghion, P., \& Tirole, J. (1994). The management of innovation. Quarterly Journal of Economics, 109(4), 1185-1209.

Aghion, P., Van Reenen, J., \& Zingales, L. (2013). Innovation and institutional ownership. American Economic Review, 103(1), 277-304.

Aghion, P., Askenazy, P., Berman, N., Cette, G., \& Eymard, L. (2012). Credit constraints and the cyclicality of R\&D investment: Evidence from France. Journal of the European Economic Association, 10(5), 10011024.

Akcigit, U. \& Kerr, W.R. (2012). Growth through heterogeneous innovations. NBER Working Paper No. 16443.

Anton, J.J., \& Yao, D. (1995). Start-ups, spin-offs, and internal projects. Journal of Law, Economics \& Organization, 11(2), 362-378.

Atanassov, J. (2013). Do hostile takeovers stifle innovation? Evidence from antitakeover legislation and corporate patenting. Journal of Finance, 68(3), 1097-1131.

Beck, T., Demirgüç-Kunt, A., Laeven, L., \& Levine, R. (2008). Finance, firm size, and growth. Journal of Money Credit and Banking, 40, 1379-1405.

Bergemann, D., \& Hege, U. (1998). Venture capital financing, moral hazard and learning. Journal of Banking and Finance, 22(6-8), 703-735.

Bergemann, D., \& Hege, U. (2005). The financing of innovation: Learning and stopping. RAND Journal of Economics, 36(4), 719-752.

Berkowitz, J., \& White, M. (2004). Bankruptcy and small firms' access to credit. RAND Journal of Economics, 35(1), 69-84. 
Bernstein, S. (2014). Does going public affect innovation? Forthcoming, Journal of Finance.

Bernstein, S., Giroud, X., \& Townsend, R. (2014). The impact of venture capital monitoring: Evidence from a natural experiment. Working Paper.

Bertrand, M., Schoar, A., \& Thesmar, D. (2007). Banking deregulation and industry structure: Evidence from the 1985 French banking act. Journal of Finance, 62(2), 597-628.

Black, B.S., \& Gilson, R.J. (1998). Venture capital and the structure of capital markets: Banks versus stock markets. Journal of Financial Economics, 47(3), 243-277.

Black, S., \& Strahan, P. (2002). Entrepreneurship and bank credit availability. Journal of Finance, 57(6), 2807-2833.

Bloom, N., Schankerman, M., \& Van Reenen, J. (2013). Identifying technology spillovers and product market rivalry. Econometrica, 81(4), 1347-1393.

Bozkaya, A., \& Kerr. W. (2014) Labor regulations and European venture capital. Journal of Economics and Management Strategy, 23(4), 776-810.

Brown, J.R., Fazzari, S.M., \& Petersen, B.C. (2009). Financing innovation and growth: Cash flow, external equity, and the 1990s R\&D boom. Journal of Finance, 64(1), 151-185.

Brown, J.R., Martinsson, G., \& Petersen, B.C. (2012). Do financing constraints matter for R\&D?. European Economic Review, 56(8), 1512-1529.

Bushee, B.J. (1998). The influence of institutional investors on myopic R\&D investment behavior. Accounting Review, 73(3), 305-333.

Cagetti, M., \& De Nardi, M. (2006). Entrepreneurship, frictions and wealth. Journal of Political Economy, 114(5), 835-870.

Carlino, G., \& Kerr, W.R. (2014). Agglomeration and innovation. Harvard Business School Working Paper No. 15-007.

Cerqueiro, G., Hegde, D., Penas, M.F., \& Seamans, R. (2014). Debtor rights, credit supply, and innovation. Working paper.

Cetorelli, N., \& Strahan, P.E. (2006). Finance as a barrier to entry: bank competition and industry structure in local U.S. markets. Journal of Finance, 61(1), 437-461.

Chava, S., Oettl, A., Subramanian, A., \& Subramanian, K.V. (2013). Banking deregulation and innovation. Journal of Financial Economics, 109(3), 759-774.

Chava, S., Chong, X., \& Nanda, V. (2012). Funding innovation: The role of lender expertise and control rights. Georgia Institute of Technology Working Paper. 
Chemmanur, T., Krishnan, K., \& Nandy, D.K. (2011). How does venture capital financing improve efficiency in private firms? A look beneath the surface. Review of Financial Studies, 24(12), 4037-4090.

Chemmanur, T., Loutskina, E., \& Tian, X. (2014). Corporate venture capital, value creation, and innovation. Review of Financial Studies, 27(8), 2434-2473

Chemmanur, T., \& Tian, X. (2012). Do anti-takeover provisions spur corporate innovation? AFA 2012 Chicago Meetings Paper.

Cohen, S., \& Hochberg, Y. (2014). Accelerating startups: The seed accelerator phenomenon. Working paper.

Comin, D., \& Nanda, R. (2014). Financial development and technology diffusion. Working paper.

Cornaggia, J., Mao, Y., Tian, X., \& Wolfe, B. (2013). Does banking competition affect innovation?. Forthcoming, Journal of Financial Economics.

Cumming, D., \& Johan, S. (2009). Venture Capital and Private Equity Contracting: An International Perspective, Elsevier Science Academic Press.

Da Rin, M., Hellmann, T., \& Puri, M. (2013). A survey of venture capital research. In Handbook of the Economics of Finance 2(A), eds. Constantinides, G., Harris, M., \& Stulz, R., Amsterdam: North Holland.

Ederer, F., \& Manso, G. (2011). Incentives for innovation: Bankruptcy, corporate governance, and compensation systems. In Handbook of Law, Innovation, and Growth, Edward Elgar Publishing.

Edmans, A. (2009). Blockholder trading, market efficiency, and managerial myopia. Journal of Finance, 64(6), 2481-2513.

Ewens, M., \& Fons-Rosen, C. (2013). The consequences of entrepreneurial firm founding on innovation. Working paper.

Ewens, M., Nanda, R., \& Rhodes-Kropf, M. (2014). Entrepreneurship and the cost of experimentation. Working paper.

Fabrizio, K., (2007). Financing innovation in the United States, 1870 to the present. In The Federal Role in Financing Major Innovations: Information Technology During the Postwar Period, eds. Lamoreaux, N., \& Sokoloff, K., MIT Press.

Fallick, B., Fleischman, C.A., \& Rebitzer, J.B. (2006). Job-hopping in Silicon Valley: Some evidence concerning the microfoundations of a high-technology cluster. Review of Economics and Statistics, 88(3), 472-481.

Fang, V. W., Tian, X., \& Tice, S. (2013). Does stock liquidity enhance or impede firm innovation?. Journal of Finance, 69(5), 2085-2125. 
Ferreira, D., Manso, G., \& Silva, A.C. (2014). Incentives to innovate and the decision to go public or private. Review of Financial Studies, 27, 256-300.

Field, A. (2003). The most technologically progressive decade of the twentieth century. American Economic Review, 93(4), 1399-1413.

Francis, J., \& Smith, A. (1995). Agency costs and innovation some empirical evidence. Journal of Accounting and Economics, 19(2), 383-409.

Gans, J. S., Hsu, D. H., \& Stern, S. (2002). When does start-up innovation spur the gale of creative destruction?. RAND Journal of Economics, 33(4), 571-586.

Gompers, P.A. (1995). Optimal investment, monitoring, and the staging of venture capital. Journal of Finance, 50(5), 1461-1489.

Gompers, P., Lerner, J., \& Scharfstein, D. (2005). Entrepreneurial spawning: Public corporations and the genesis of new ventures, 1986 to 1999. Journal of Finance, 60(2), 577-614.

Gonzales-Uribe, J., \& Xu, M. (2014). CEO investment horizon and innovation. Working paper.

Grossman, S.J., Hart, O.D. (1986). The costs and benefits of ownership: A theory of vertical and lateral integration. Journal of Political Economy, 94, 691-719

Guedj, I., \& Scharfstein, D. (2004). Organizational scope and investment: Evidence from the drug development strategies and performance of biopharmaceutical firms. NBER Working Paper No. 10933.

Hall, B., \& Lerner, J. (2010). The financing of R\&D and innovation. In Handbook of the Economics of Innovation, eds. Hall, B., \& Rosenberg. N., Netherlands: Elsevier, 609-639.

Hall, B.H., Griliches, Z., \&. Hausman, J.A. (1986). Patents and R\&D: Is there a lag?. International Economic Review, 27(2), 265-283.

Hart, O., \& Moore, J. (1990). Property rights and the nature of the firm. Journal of Political Economy, 98, 1119-1158.

He, J.J., \& Tian, X. (2013). The dark side of analyst coverage: The case of innovation. Journal of Financial Economics, 109(3), 856-878.

Hellmann, T. (2007). When do employees become entrepreneurs?. Management Science, 53(6), 919933.

Hellmann, T., \& Puri, M. (2000). The interaction between product market and financing strategy: The role of venture capital. Review of Financial Studies, 13(4), 959-984.

Hellmann, T., \& Puri, M. (2002). Venture capital and the professionalization of start-up firms: Empirical evidence. Journal of Finance, 57(1), 169-197. 
Hochberg, Y., Serrano, C., \& Ziedonis, R. (2014). Patent collateral, investor commitment, and the market for venture lending. NBER Working Paper No. 20587.

Holmstrom, B. (1982). Managerial incentive problems - A dynamic perspective. In Essays in Economics and Management in Honor of Lars Wahlbeck, Helsinki: Swedish School of Economics.

Holmstrom, B. (1989). Agency costs and innovation. Journal of Economic Behavior \& Organization, 12(3), 305-327.

Howell, S. (2014). Financing constraints as barriers to innovation: Evidence from R\&D grants to energy startups. Working paper.

Hsu, P.H., Tian, X., \& Xu, Y. (2014). Financial development and innovation: Cross-country evidence. Journal of Financial Economics, 112(1), 116-135.

Jayaratne, J., \& Strahan, P.E. (1996). The finance-growth nexus: Evidence from bank branch deregulation. Quarterly Journal of Economics, 111(3), 639-670.

Kerr, W.R., Lerner, J., \& Schoar, A. (2014). The consequences of entrepreneurial finance: Evidence from angel financings. Review of Financial Studies, 27(1), 20-55.

Kerr, W.R., \& Lincoln, W.F. (2010). The supply side of innovation: H-1B visa reforms and US ethnic invention. Journal of Labor Economics, 28(3), 473-508.

Kerr, W.R., \& Nanda, R. (2009). Democratizing entry: Banking deregulations, financing constraints, and entrepreneurship. Journal of Financial Economics, 94, 124-149.

Kerr, W.R., Nanda, R., \& Rhodes-Kropf, M. (2014). Entrepreneurship as experimentation. Journal of Economic Perspectives, 28(3), 25-48.

King, R.G., \& Levine, R. (1993a). Finance, entrepreneurship and growth: theory and evidence. Journal of Monetary Economics, 32, 513-542.

King, R.G., \& Levine, R. (1993b). Finance and growth: Schumpeter might be right. Quarterly Journal of Economics, 108, 717-737.

Knight, F.H. (1921). Risk, Uncertainty, and Profit. Boston, MA: Houghton Mifflin.

Kogan, L., Papanikolaou, D., Seru, A., \& Stoffman, N. (2012). Technological innovation, resource allocation, and growth. NBER Working Paper No. 17769.

Kortum, S., \& Lerner, J. (2000). Assessing the contribution of venture capital to innovation. RAND Journal of Economics, 31(4), 674-692.

Lerner, J. (1995). Venture capitalists and the oversight of private firms. Journal of Finance, 50(1), 301318. 
Lerner, J. (1999). The government as venture capitalist: The long-run impact of the SBIR program. Journal of Business, 72(3), 285-318.

Lerner, J. (2012). The Architecture of Innovation: The Economics of Creative Organizations. Boston, MA: Harvard Business School Press.

Lerner, J., \& Seru, A. (2014). The use and abuse of patent data. Working Paper.

Lerner, J., Sorensen, M., \& Strömberg, P. (2011). Private equity and long-run investment: The case of innovation. Journal of Finance, 66(2), 445-477.

Lerner, J., \& Wulf, J. (2007). Innovation and incentives: Evidence from corporate R\&D. Review of Economics and Statistics, 89(4), 634-644.

Levine, R. (1997). Financial development and economic growth: views and agenda. Journal of Economic Literature, 688-726.

Mann, W. (2014). Creditor rights and innovation: Evidence from patent collateral. Working paper.

Manso, G. (2011). Motivating innovation. Journal of Finance, 66(5), 1823-1860.

Nanda, R., \& Nicholas, T. (2014) Did bank distress stifle innovation during the Great Depression?. Journal of Financial Economics, 114(2), 273-292.

Nanda, R., \& Rhodes-Kropf, M. (2010). Financing risk and innovation. Harvard Business School Working Paper No. 11-013.

Nanda, R., \& Rhodes-Kropf, M. (2013). Investment cycles and startup innovation. Journal of Financial Economics, 110(2), 403-418.

Nanda, R., \& Rhodes-Kropf, M. (2012). Innovation and the financial guillotine. Harvard Business School Working Paper No. 13-038.

Nanda, R., Younge, K., \& Fleming, L. (2015). Innovation and entrepreneurship in renewable energy. In The Changing Frontier: Rethinking Science and Innovation Policy, eds. Jaffe, A., and Jones, B., National Bureau of Economic Research.

Nicholas, T. (2011). What drives innovation?. Antitrust Law Journal, 77(3), 787-809.

Pástor, L'., \& Veronesi, P. (2009). Technological revolutions and stock prices. American Economic Review, 99(4), 1451-1483.

Raff, D.M., \& Trajtenberg, M. (1996). Quality-adjusted prices for the American automobile industry: 1906-1940. In The Economics of New Goods, University of Chicago Press, 71-108.

Rajan, R.G. \& Zingales, L. (1998). Financial dependence and growth. American Economic Review, 88(3), 559-586. 
Robb, A.M., \& Robinson, D.T. (2012). The capital structure decisions of new firms. Review of Financial Studies, 27(1), 153-179.

Saint-Paul, G. (1997). Is labour rigidity harming Europe's competitiveness? The effect of job protection on the pattern of trade and welfare. European Economic Review, 41(3), 499-506.

Saint-Paul, G. (2002). Employment protection, international specialization, and innovation. European Economic Review, 46(2), 375-395.

Samaniego, R.M. (2006). Employment protection and high-tech aversion. Review of Economic Dynamics, 9(2), 224-241.

Samila, S., \& Sorenson, O. (2011). Venture capital, entrepreneurship, and economic growth. Review of Economics and Statistics, 93(1), 338-349.

Scherer, F.M. (1984). Innovation and Growth: Schumpeterian Perspectives. Cambridge Massachusetts: MIT Press.

Scherer, F.M., \& Harhoff, D. (2000). Technology policy for a world of skew-distributed outcomes. Research Policy, 29(4-5), 559-566.

Schumpeter, J. (1934). The Theory of Economic Development: An Inquiry into Profits, Capital, Credit, Interest and the Business Cycle. Cambridge, MA: Harvard University Press.

Seru, A. (2014). Firm boundaries matter: Evidence from conglomerates and R\&D activity. Forthcoming, Journal of Financial Economics.

Stein, J. (1988). Takeover threats and managerial myopia. Journal of Political Economy, 96, 61-80.

Trajtenberg, M. (1990). A penny for your quotes: Patent citations and the value of innovations. Rand Journal of Economics, 1, 172-187.

Wasserman, N. (2003). Founder-CEO succession and the paradox of entrepreneurial success.

Organization Science, 14, 2149-2172

Williams, H. (2013). Intellectual property rights and innovation: Evidence from the human genome. Journal of Political Economy, 121(1), 1-27.

Yu, S. (2014). The impact of accelerators on high-technology ventures. Working paper. 